\title{
Model internacjonalizacji ukraińskich mikro i małych firm
}

\author{
Beata Glinkowska-Krauze ${ }^{\star}$
}

\begin{abstract}
Streszczenie. Opracowanie dotyczy analizy sposobu (sposobów) internacjonalizacji mikro i małych przedsiębiorstw ukraińskich. Zawiera takie elementy składowe jak: wstęp, analizę warunków funkcjonowania małych przedsiębiorstw na Ukrainie, analizę wyników badań własnych w związku z takimi elementami, jak: rozumienie istoty procesu internacjonalizacji, motywy i bariery internacjonalizacji niewielkich ukraińskich przedsiębiorstw, stosowane przez nie strategie internacjonalizacji. We wstępie zawarto cel opracowania i charakterystykę własnych badań empirycznych. Opisano sposoby internacjonalizacji małych ukraińskich przedsiębiorstw. Opracowanie zakończone jest podsumowaniem odnoszącym się do całości podjętych rozważań. Najważniejszy wniosek z badań: małe ukraińskie przedsiębiorstwa stosują „wczesną internacjonalizację”.
\end{abstract}

Słowa kluczowe: internacjonalizacja, małe i średnie przedsiębiorstwa, born global, przedsiębiorstwo, Ukraina.

\section{Wprowadzenie}

Internacjonalizacja działalności gospodarczej jest jednym ze sposobów rozwoju i wzrostu współczesnych przedsiębiorstw. Wynika to przede wszystkim z ograniczeń możliwości rozwoju działalności gospodarczej na rynku kraju macierzystego oraz z istnienia zróżnicowanych możliwości rozwoju i wzrostu poza granicami własnego kraju. Z perspektywy badacza interesujące wydaje się, jak przedsiębiorstwa w poszczególnych krajach rozpoczynają własną internacjonalizację. Czy sposób ich internacjonalizacji w konkretnym kraju i dla wybranego sektora firm wykazuje jakieś podobieństwa, czy też jest zróżnicowany. To, w jaki sposób przedsiębior-

* Uniwersytet Łódzki, Wydział Zarządzania. 
cy rozumieją istotę internacjonalizacji i jak internacjonalizują się mikro i małe przedsiębiorstwa na Ukrainie było podstawowym pytaniem problemowym dla autorki tego opracowania. W literaturze przedmiotu nie ma zwartych opracowań odnoszących się do internacjonalizacji działalności ukraińskich przedsiębiorstw (istoty, strategii, form, motywów, barier). Nie ma też opracowań dotyczących modeli internacjonalizacji działalności mikro i małych przedsiębiorstw. Wypełniając tę lukę, celem opracowania jest prezentacja sposobu (sposobów) „wejścia” na rynki zagraniczne ukraińskich mikro i małych firm. Mikro i małe firmy na Ukrainie działają w oparciu o ustawę Kodeks Handlowy Ukrainy z 2003 r. ${ }^{1}$

Badania zostały wykonane na Ukrainie, osobiście, w latach 2015-2017 na próbie 17 mikro i małych ukraińskich przedsiębiorstw, które w sposób pośredni lub bezpośredni kooperują z zagranicznymi przedsiębiorcami, na zasadzie poziomych więzi współpracy. Badane przedsiębiorstwa reprezentują handlowy, przetwórczy i usługowy zakres działalności oraz zróżnicowane branże: odzieżową, spożywczą, metalową, zarządzania nieruchomościami, remontowo-budowlaną. Istnieją na rynku 3-7 lat. Taki dobór firm do badań był celowy. Narzędziem badawczym był kwestionariusz ankiety i kwestionariusz wywiadu standaryzowany, z możliwością swobodnej wypowiedzi. Zanalizowano też dane dotyczące stanu wybranych zagadnień na oficjalnej stronie Państwowej Służby Statystyki Ukrainy oraz wykonano analizę SWOT dla próby badawczej.

\section{Mikro i małe przedsiębiorstwa na Ukrainie - warunki funkcjonowania}

Podstawą regulacyjną i prawną prowadzenia działalności gospodarczej na Ukrainie przez małe i średnie przedsiębiorstwa jest Kodeks Handlowy Ukrainy przyjęty w 2003 r. Artykuł 55 tego dokumentu pt. „Koncepcja podmiotu gospodarczego”, po licznych edycjach i wyjaśnieniach został ostatecznie ustalony i przyjęty w $2013 \mathrm{r}^{2}$ Przedsiębiorczość stanowi ważny i integralny komponent gospodarki rynkowej. Pozwala na mobilizację istniejących zasobów i przyspiesza tempo jej rozwoju. Poziom przedsiębiorczości w każdym kraju zależy od ilości i stanu przedsiębiorstw. Trzonem większości gospodarek rynkowych są małe i średnie przedsiębiorstwa, które w wielu

1 Kryteria klasyfikacji firm przyjęte na Ukrainie w kwestii ilości zatrudnionych są analogiczne jak w przypadku firm polskich, https://ips.ligazakon.net/document/view/T030436?bl= [dostęp 10.06.2018].

2 Kodeks handlowy Ukrainy nr 436-IV z 16 stycznia 2003 r., Biuletyn Rady Najwyższej Ukrainy, 2003, nr 18, nr 19-20, nr 21-22, art. 144. 
rozwiniętych gospodarczo krajach wytwarzają minimum 50\% $\mathrm{PKB}^{3}$. Na Ukrainie małe i średnie przedsiębiorstwa tworzą łącznie około 15\% PKB, co jest stosunkowo niskim wskaźnikiem ${ }^{4}$. Nadmienić należy, że w 2014 r. PKB w Ukrainie wyniósł minus (-) 6,6\%, w 2015 r. - minus (-) 9,8\%, w 2016 r. - plus (+) 2,3\%, a w 2017 r. - plus (+) $2,2 \%$. Z przytoczonych wartości wynika, że gospodarka od 2016 r. zaczęła się stabilizować. Przewiduje się, że w 2018 r. PKB dla Ukrainy wyniesie 3,5\%5. Oznaczać może to pozytywny klimat nie tylko dla inwestowania na terenie Ukrainy, ale także rozwój indywidualnej przedsiębiorczości. Jednakże, aktualnie przedsiębiorcy na Ukrainie napotykają wiele barier na drodze do rozwoju własnych firm, związanych przede wszystkim: $\mathrm{z}$ brakiem kapitałów własnych; stosunkowo wysokimi stopami procentowymi kredytów (do 24\%), co utrudnia dofinansowanie kapitałami obcymi w postaci kredytów; z brakiem istotnego wsparcia przez rząd oraz z niekorzystną sytuacją ekonomiczną i polityczną. W najtrudniejszej sytuacji są obwody: doniecki i Ługański, czego głównym powodem są prowadzone tam działania wojenne. Niewielka stabilność warunków funkcjonowania dla małych przedsiębiorstw jest natomiast powodem tego, że około $80 \%$ z nich kończy swoją działalność w okresie od jednego roku do dwóch lat od momentu otworzenia działalności ${ }^{6}$. Prawie $40 \%$ przedsiębiorstw mikro i małych jest nierentownych lub wykazuje niską rentowność. Najmniejszą rentownością cechują się przedsiębiorstwa $\mathrm{z}$ branży budowlanej ${ }^{7}$ i ogólnoprzemysłowej. Obniża się też z roku na rok wskaźnik zatrudnienia w małych firmach ${ }^{8}$, czego powodem może być wprowadzanie nowych technologii, wysokie opodatkowanie firm, istnienie dużej tzw. „szarej strefy” oraz niska rentowność przedsiębiorstw i związana z tym konieczność redukcji kosztów. Stosunkowo najlepszą rentowność wykazują natomiast małe firmy funkcjonujące w takich sektorach, jak: rolnictwo, leśnictwo, finanse i handel. Nadmienić należy także, że nie odnotowuje się pogorszenia wskaźnika związanego ze zmniejszającą się rentownością małych przedsiębiorstw, natomiast od czasów globalnego kryzysu, czyli od $2008 \mathrm{r}$. do chwili obecnej można zauważyć sukcesywną poprawę takich wskaźników, jak: wartość sprzedaży produktów, średnia roczna pensja pracowników z sektora małych przedsiębiorstw, wzrost rentowności operacyjnej’. Istotną dolegliwością dla sekto-

3 http://stat.gov.pl/statystyka-miedzynarodowa/porownania-miedzynarodowe/tabliceo-krajach-wedlug-tematow/ [dostęp 7.01.2018].

4 I. M. Epifanova, Kluczowe aspekty rozwoju małych przedsiębiorstw na Ukrainie, Materiały Uniwersytetu Odeskiej Politechniki 2009, Politechnika Odeska, nr 1 (31), s. 211-215.

5 The World Bank, http://www.worldbank.org/en/region/eca/publication/europe-and-central-asia-economic-update [dostęp 8.01.2018].

6 N. Chukhray, Rozwój przedsiębiorczości w Ukrainie - główne problemy oraz perspektywy, [w:] A. Jackiewicz, Ł. Sułkowski (red.), Przedsiębiorczość i zarzadzanie, Wydawnictwo SAN, t. XIV, zesz. 8, cz. 1, Łódź 2013, s. 45-60.

7 W ostatnich kilku latach rynek budowlany wykazuje jednak tendencję rozwojową (Ukraina, 2017, badania własne).

8 Państwowa Służba Statystyki Ukrainy, http://www.ukrstat.gov.ua/ [dostęp 7.01.2018].

9 Ibidem. 
ra mikro i małych firm na Ukrainie jest istnienie, na dużą skalę, „szarej strefy”, zachowań korupcyjnych i monopolizowanie gospodarki przez duże przedsiębiorstwa państwowe. Wskazane mankamenty $\mathrm{w}$ prowadzeniu działalności gospodarczej na Ukrainie stają się często w praktyce zasadniczymi motywami dla poszukiwania lepszych warunków prowadzenia biznesu poza granicami kraju macierzystego, co staje się podstawą internacjonalizacji ich działalności gospodarczej.

\section{Istota procesu internacjonalizacji działalności}

Jednym z problemów badawczych, które autorka założyła, było rozumienie istoty internacjonalizacji działalności przez ukraińskich przedsiębiorców, będących właścicielami mikro i małych firm. Celem tych badań było uzyskanie możliwości porównania $\mathrm{z}$ istniejącymi $\mathrm{w}$ literaturze przedmiotu definicjami tego pojęcia. $\mathrm{W}$ tabeli 1 . zawarto wyniki badań pochodzące $\mathrm{z}$ wywiadu.

Tabela 1. Rozumienie istoty internacjonalizacji

\begin{tabular}{|l|c|}
\hline \multicolumn{1}{|c|}{ Istota internacjonalizacji } & $\begin{array}{c}\text { Liczba odpowiedzi } \\
\mathbf{N}=\mathbf{1 7}\end{array}$ \\
\hline Umiędzynarodowienie działalności & 6 \\
\hline $\begin{array}{l}\text { Prowadzenie eksportu i importu towarów w sposób pośredni (na tere- } \\
\text { nie własnego kraju z firmami pośredniczącymi) i bezpośredni } \\
\text { (z firmami z zagranicy na terenie własnego kraju i poza jego granicami) }\end{array}$ & 5 \\
\hline $\begin{array}{l}\text { Współpraca pomiędzy przedsiębiorstwami z różnych krajów (koopera- } \\
\text { cja międzynarodowa) }\end{array}$ & 4 \\
\hline Rozszerzenie działalności na obce rynki (rynki goszczące) & 1 \\
\hline $\begin{array}{l}\text { Funkcjonowanie na rynkach zagranicznych w ramach prowadzonej } \\
\text { tam działalności gospodarczej (bezpośrednie inwestycje zagraniczne) }\end{array}$ & 1 \\
\hline
\end{tabular}

Źródło: opracowanie własne, Ukraina, 2017.

Analizując poszczególne odpowiedzi, można zauważyć, że najczęściej proces ten jest postrzegany jako umiędzynarodowienie działalności, a następnie jako eksport i import towarów oraz współpraca rozumiana jako kooperacja międzynarodowa i rozszerzenie działalności na obce rynki. W literaturze przedmiotu można napotkać wiele zróżnicowanych poglądów, pozwalających na postrzeganie tego procesu w sposób złożony. Spośród nich dominuje ten, w którym internacjonalizację rozumie się jako każde działanie gospodarcze, podejmowane przez przedsiębiorstwo 
za granicą ${ }^{10}$ albo jako zaangażowanie się firmy w działalność międzynarodową ${ }^{11}$ czy też: eksport i import produktów/surowców lub przenoszenie produkcji poza granice kraju macierzystego ${ }^{12}$. Jest to proces dynamiczny, związany z rozwojem przedsiębiorstw ${ }^{13}$. Dotyczy zarówno firm krajowych, mających swoje aktywa zlokalizowane tylko w jednym, jak i w dwóch lub większej liczbie krajów ${ }^{14}$. Proces ten można rozpatrywać w charakterze korzyści dla przedsiębiorstw, także jako ten, podczas którego przedsiębiorstwo wchodzi w relacje $\mathrm{z}$ innymi podmiotami, realizując swoje strategiczne cele ${ }^{15}$ lub jako ten, który prowadzi do wzrostu powiązań między krajami i przedsiębiorstwami ${ }^{16}$.

Istotą internacjonalizacji jest więc prowadzenie działalności gospodarczej w kooperacji z przedsiębiorstwami z zagranicy, jak i poza granicami kraju, w postaci bezpośrednich inwestycji zagranicznych. Internacjonalizacja jest rozumiana też jako proces ekspansji międzynarodowej, realizowanej poprzez zróżnicowane formy, określane jako formy internacjonalizacji, co wyniki badań potwierdzają.

\section{Formy internacjonalizacji ukraińskich mikro i małych przedsiębiorstw}

Przez formę internacjonalizacji należy rozumieć sposób zorganizowania współpracy (współdziałania, kooperacji) rozpoczynającej funkcjonowanie na rynkach zagranicznych lub z przedsiębiorcami spoza granic kraju macierzystego ${ }^{17}$. Wykonane badania własne pokazały, że mikro i małe przedsiębiorstwa ukraińskie stosują zróżnicowane formy internacjonalizacji (tabela 2).

10 J. Rymarczyk, Internacjonalizacja i globalizacja przedsiębiorstwa, PWE, Warszawa 2004, s. 19.

11 J. Johanson, J. R. Vahlne, The Internationalization Process of the Firm - A Model of Knowledge Development and Increasing Commitments, "Journal of International Business Studies" 1977, vol. 8, no 1, s. 73.

12 P. Pietrasieński, Międzynarodowe strategie marketingowe, PWE, Warszawa 2005, s. 15.

13 B. Glinkowska, B. Kaczmarek, Zarządzanie międzynarodowe $i$ internacjonalizacja przedsiębiorstw. Teoria i praktyka, Wydawnictwo UŁ, Łódź 2016a, s. 20-27.

14 Z. Pierścionek, Zarządzanie strategiczne w przedsiębiorstwie, Wydawnictwo Naukowe PWN, Warszawa 2011, s. 359.

15 L. S. Welch, R. K. Luostarinen, Internationalization: Evolution of a Concept, [w:] K. Przybylska, Born Global nowa generacja małych przedsiębiorstw, Uniwersytet Ekonomiczny w Krakowie, Kraków 2013, s. 19.

16 M. Rozkwitalska, Zarządzanie międzynarodowe, Difin sp. z o.o., Warszawa 2007, s. 184.

17 K. Wach, Skutki akcesji do Unii Europejskiej dla polskich przedsiębiorstw, Wydawnictwo Uniwersytetu Ekonomicznego w Krakowie, Kraków 2008, s. 50-53. 
Tabela 2. Formy internacjonalizacji stosowane przez ukraińskie organizacje*

\begin{tabular}{|l|c|}
\hline \multicolumn{1}{|c|}{ Forma internacjonalizacji } & $\begin{array}{c}\text { Liczba } \\
\text { przedsiębiorstw } \\
\text { (N = 17) }\end{array}$ \\
\hline Import pośredni (poprzez pośrednika) & 3 \\
\hline Import bezpośredni (osobiście, bezpośrednio) & 4 \\
\hline Eksport pośredni (poprzez pośrednika) & 6 \\
\hline Eksport bezpośredni (osobiście, bezpośrednio) & 7 \\
\hline Kooperacja produkcyjna & 5 \\
\hline Alians strategiczny & 2 \\
\hline Licencja & 0 \\
\hline Franchising & 0 \\
\hline Bezpośrednia inwestycja zagraniczna & 0 \\
\hline
\end{tabular}

* Możliwość wielokrotnego wyboru.

Źródło: opracowanie własne, Ukraina, 2017.

Poddane badaniom przedsiębiorstwa najczęściej stosują eksport (pośredni i bezpośredni - 13) oraz kooperację produkcyjną (5), a następnie import (pośredni i bezpośredni - 7), jako najbardziej popularne formy internacjonalizacji. Import i eksport są stosunkowo prostymi formami, niewymagającymi wielkich nakładów finansowych, przynoszącymi pozytywne rezultaty ekonomiczne praktycznie od początku ich stosowania. Kooperacja produkcyjna i alians strategiczny wymagają dobrze opracowanych umów, zaufania oraz ścisłego współdziałania w ramach wykonywanych wspólnych projektów. Często też przynoszą pozytywne rezultaty ekonomiczne po pewnym czasie, co jest powodem mniejszej ich atrakcyjności dla przedsiębiorstw o niewielkim kapitale własnym, czyli dla mikro i małych firm na Ukrainie. Ponadto, bardziej złożone formy wymagają większej intensywności zaangażowania firmy za granicą i zwiększenia zakresu kontroli ${ }^{18}$, co z kolei wymaga więcej czasu i środków finansowych. Dla ukraińskich mikro i małych firm dokuczliwy jest brak wystarczającego kapitału dla tworzenia bezpośrednich inwestycji zagranicznych lub dla rozwoju działalności na własnym rynku, czyli na terenie Ukrainy. Ten ostatni aspekt jest wynikiem stosunkowo licznej i mało sformalizowanej konkurencji („szara strefa”) na rynku kraju macierzystego. Niskie koszty funkcjonowania niezarejestrowanych działalności gospodarczych przekładają się na niskie ceny rynkowe produktów i usług, czego podmioty zarejestrowane, dzia-

18 J. Rymarczyk, op. cit., s. 156. 
łające legalnie, nie są w stanie osiągnąć, stąd niska jest ich atrakcyjność dla klientów. Jest to zasadniczym powodem poszukiwania możliwości funkcjonowania i rozwoju działalności poza granicami własnego kraju. W takich okolicznościach eksport i import stają się często podstawą do rozwoju współpracy w ramach właśnie kooperacji produkcyjnej lub aliansu strategicznego.

\section{Motywy i bariery internacjonalizacji ukraińskich mikro i małych przedsiębiorstw}

Motywy, czyli determinanty internacjonalizacji przedsiębiorstw oraz bariery na drodze do internacjonalizacji należy rozpatrywać w związku z zasadniczymi aspektami, do których należą m.in.: warunki funkcjonowania i rozwoju na własnym rynku (określanym jako rynek macierzysty); możliwości funkcjonowania i rozwoju na rynku zagranicznym (określanym jako rynek kraju goszczącego) ${ }^{19}$; siła, ilość i jakość posiadanych atutów; ilość, siła i jakość słabości przedsiębiorstwa. Wymaga to wykonania przez przedsiębiorstwo analizy jego mocnych i słabych stron oraz szans i zagrożeń $w$ otoczeniu ${ }^{20}$ zarówno kraju macierzystego, jak i goszczącego.

Wykonana w procesie badań ukraińskich przedsiębiorstw analiza SWOT wykazała przede wszystkim słabości związane z brakiem kapitału własnego i brakiem nowoczesnych, zaawansowanych technologii. Do mocnych stron badane firmy zaliczyły głównie dobre jakościowo produkty/usługi oraz niskie koszty ich wytworzenia, a także tradycyjne procedury. Te mocne strony mają dla przedsiębiorców dużą wagę. Odnotowano stosunkowo wiele zagrożeń wynikających przede wszystkim z: niewielkich możliwości wsparcia własnej działalności zewnętrznym finansowaniem, istnienia licznej „szarej strefy” na rynku kraju macierzystego, niesprzyjających przepisów prawa dla rozwoju małych firm, nadmiernego doceniania firm dużych, kosztem właśnie tych małych, niewielkich dochodów mieszkańców Ukrainy, istnienia w niektórych okręgach (obwodach) niesprzyjających nastrojów z powodu działań wojennych (np. Donieck, Ługańsk). Na rynkach zagranicznych zagrożeniem niejednokrotnie natomiast są zawiłe przepisy, kosztowne dostosowania działalności do wymogów danego rynku, jak też wysokie kary finansowe za prawne uchybienia. Szans na rynkach krajów goszczących badane firmy upatrują przede wszystkim w zliberalizowanych dla handlu warunkach funkcjonowania

19 B. Glinkowska, B. Kaczmarek, Zarządzanie międzynarodowe. Strategie i studia przypadków, Wydawnictwo Ut, Łódź 2016b, s. 25.

20 G. Gierszewska, M. Romanowska, Analiza strategiczna przedsiębiorstwa, wyd. VII, PWE S.A., Warszawa 2017. 
i postępujących procesach globalizacyjnych. Wyciągając wnioski z przeprowadzonej analizy SWOT, jak również analizując wyniki uzyskanych badań w zakresie motywów i barier internacjonalizacji, w tabeli 3. zawarto najważniejsze motywy internacjonalizacji ukraińskich małych przedsiębiorstw, a w tabeli 4. związane z internacjonalizacją bariery.

Tabela 3. Motywy internacjonalizacji ukraińskich przedsiębiorstw*

\begin{tabular}{|l|c|}
\hline \multicolumn{1}{|c|}{ Motywy } & $\begin{array}{c}\text { Liczba } \\
\text { przedsiębiorstw } \\
\text { (N = 17) }\end{array}$ \\
\hline Zwiększenie przychodów i zysków netto & 17 \\
\hline Możliwość rozwoju & 12 \\
\hline $\begin{array}{l}\text { Małe możliwości sprzedaży na rynku macierzystym i silna konkuren- } \\
\text { cja }\end{array}$ & 15 \\
\hline $\begin{array}{l}\text { Chęć znalezienia niszy dla własnych produktów na rynku/ach } \\
\text { goszczących }\end{array}$ & 4 \\
\hline Dostęp do nowych technologii & 4 \\
\hline Istnienie luk prawnych & 1 \\
\hline Sprzyjające przepisy prawa na rynku goszczącym & 2 \\
\hline Niesprzyjające przepisy prawa na rynku macierzystym & 11 \\
\hline Prestiż, moda & 2 \\
\hline Motywy osobiste i znajomość rynku goszczącego & 9 \\
\hline $\begin{array}{l}\text { Brak surowców/materiałów na rynku macierzystym lub niższe ich } \\
\text { ceny na rynku goszczącym }\end{array}$ & 5 \\
\hline
\end{tabular}

* Możliwość wielokrotnych odpowiedzi.

Źródło: opracowanie własne, Ukraina, 2017.

$\mathrm{Z}$ analizy danych zawartych $\mathrm{w}$ tabeli 3. wynika, iż zasadniczymi motywami internacjonalizacji działalności dla małych przedsiębiorstw na Ukrainie są: zwiększenie przychodów (17 odpowiedzi), niewielkie możliwości sprzedaży własnych produktów na rynku macierzystym (15), możliwości rozwoju działalności poza granicami kraju macierzystego (12), mało przyjazne przepisy w kraju macierzystym (11). Motywy internacjonalizacji ukraińskich mikro i małych firm wynikają jednak przede wszystkim z braku możliwości rozwoju własnej działalności na rynku kraju macierzystego i związanym z tym brakiem możliwości osiągania dużych zysków netto. Bariery internacjonalizacji zostały natomiast zawarte $\mathrm{w}$ tabeli 4 . 
Tabela 4. Bariery internacjonalizacji dla ukraińskich przedsiębiorstw*

\begin{tabular}{|l|c|}
\hline \multicolumn{1}{|c|}{ Bariery } & $\begin{array}{c}\text { Liczba } \\
\text { przedsiębiorstw } \\
\text { (N = 17) }\end{array}$ \\
\hline $\begin{array}{l}\text { Brak informacji o rynku/ach goszczących/strach przed błędami/ka- } \\
\text { rami }\end{array}$ & 11 \\
\hline Nieznajomość przepisów kraju goszczącego & 9 \\
\hline Nieznajomość języka & 9 \\
\hline Wysokie podatki/cła na rynku/ach goszczących & 7 \\
\hline Niewystarczająca jakość własnych produktów/usług & 3 \\
\hline Koszty transportu i dostaw & 4 \\
\hline Brak kapitału własnego & 17 \\
\hline Lęk przed niesolidnością kooperantów & 10 \\
\hline Bariery osobiste (np. brak wiary we własne możliwości) & 4 \\
\hline
\end{tabular}

* Możliwość wielokrotnego wyboru.

Źródło: opracowanie własne, Ukraina, 2017.

Ukraińscy przedsiębiorcy, będący właścicielami mikro i małych przedsiębiorstw są otwarci na międzynarodowe kooperacje, ale brak wsparcia w sferze informacyjnej na temat możliwości prawnych, ekonomicznych i kulturowych rozwijania działalności na rynkach goszczących (łącznie 20 wypowiedzi), jak też brak odpowiedniego kapitału własnego i lęk przed niesolidnością kooperantów (łącznie 27 wypowiedzi) są barierami o dużej wadze, utrudniającymi proces ich ekspansji zagranicznej. Przeprowadzone badania dały konkluzję, że nieznajomość języka danego kraju, jak też koszty transportu nie mają zasadniczego znaczenia dla tych przedsiębiorców.

\section{Strategie internacjonalizacji ukraińskich mikro i małych przedsiębiorstw}

Strategia dotyczy przemyślanego, względnie trwałego sposobu działań, planu działań i wskazówek postępowania w związku z realizacją celów organizacyjnych i kształtowaniem tożsamości organizacyjnej ${ }^{21}$. Wykonane w latach 2015-2017 ba-

21 K. Obłój, Strategia organizacji (wyd. II zmienione), PWE, Warszawa 2007, s. 325-337. 
dania własne dały wnioski, iż mikro i małe firmy na Ukrainie stosują najczęściej cztery podstawowe rodzaje strategii (możliwość wielokrotnego wyboru): konkurowanie ceną (17); konkurowanie jakością (13); konkurowanie technologią (9); specjalizację działalności (7). W ramach jednej firmy możliwe są do stosowania wszystkie wymienione strategie, bowiem nie mają one charakteru alternatywnego, jednakże najczęściej konkurują one ceną i jakością. Strategia niskiej ceny jest możliwa do zastosowania z powodu niskich kosztów wytworzenia (niższych niż w innych krajach np. Europy Zachodniej). Konkurowanie technologią jest tu natomiast rozumiane jako oparcie działalności na tradycyjnych technologiach i starych recepturach. Brak zmiany w stosowanych technologiach oraz brak zmian receptur to główne mocne strony dla przedsiębiorstw produkujących przede wszystkim żywność.

Strategie takie, jak: konkurowanie kosztami, wiedzą, kompetencjami czy dywersyfikacja działalności mają w analizowanych przypadkach znaczenie marginalne. $\mathrm{Z}$ takich zachowań strategicznych może wynikać chęć lokowania własnych produktów/usług do krajów o wyższym poziomie technologicznym, co zadeklarowało aż 14 badanych przedsiębiorstw. Daje to możliwość nie tylko rozwoju, ale także skorzystania na wyższej marży na sztuce produktu. Analizowane przedsiębiorstwa rzadko dokonują kompleksowych analiz strategicznych własnych działalności, bowiem nie mają na to czasu i pieniędzy (17). Nie stać ich też na reorganizację struktur w celu wyodrębnienia osobnych stanowisk lub komórek organizacyjnych, zajmujących się zagraniczną ekspansją. Są zdominowane przez duże firmy i często przez firmy niewielkie działające „na czarno”.

\section{Sposób internacjonalizacji ukraińskich mikro i małych przedsiębiorstw}

Na podstawie wykonanych badań własnych można wyciągnąć wnioski co do zasadniczego (najczęściej występującego) sposobu ich internacjonalizacji. Wydaje się, że największy wpływ na sposób wejścia na rynek zagraniczny mają takie aspekty, jak: motywy i bariery internacjonalizacji oraz formy i strategie tego procesu. Badane przedsiębiorstwa nie cechują się etapowością w procesie internacjonalizacji. Otwierając działalność gospodarczą, często od razu poszukują możliwości wejścia na rynek zagraniczny, co jest spowodowane przede wszystkim brakiem możliwości rozwoju działalności na rynku macierzystym, ale także istnieniem nielegalnie działających niewielkich firm, które cechują się niższymi kosztami funkcjonowania. Wykazują więc cechy modelu born global (globalnych od początku, urodzonych jako globalne, model nowych przedsięwzięć). Oznacza to, że otwie- 
rając działalność gospodarczą, zwykle już mają nawiązane pierwsze zagraniczne kontakty (np. poprzez znajomych, członków rodzin itp.). Szybkiej i wczesnej internacjonalizacji sprzyjają umiejętności i charyzma właścicieli firm i jej menedżerów. Mikro i małe firmy stosunkowo często nawiązują współpracę z firmami państw sąsiadujących z Ukrainą, a współpraca ta ma charakter obrotu towarowego (eksport-import) i kooperacji produkcyjnej. Są to przedsiębiorstwa, które zwykle nie mają wystarczających kapitałów dla tworzenia bezpośrednich inwestycji zagranicznych, a ich działalność opiera się często nie o innowacyjne projekty, ale o konkurencyjne cenowo i jakościowo produkty i usługi. Nie wykluczają jednak aliansu strategicznego jako złożonej formy internacjonalizacji i nie obawiają się jakości swoich produktów.

\section{Podsumowanie}

Wykonane badania własne będą kontynuowane. W roku 2018 jest przewidziany kolejny wyjazd badawczy na Ukrainę. Badania mają swoje ograniczenia w zakresie reprezentatywności, z czego autorka zdaje sobie sprawę, ale wyniki badań nasuwają pewne konkluzje. Brak informacji o potencjalnym kraju goszczącym oraz brak wystarczających kapitałów własnych są podstawowymi barierami internacjonalizacji małych firm ukraińskich i utrudniają ekspansję zagraniczną w postaci złożonych form internacjonalizacji (np. bezpośrednia inwestycja zagraniczna czy alians strategiczny). Ponadto, brak wiedzy na temat zagranicznych rynków stanowi istotną barierę wejścia na dany rynek goszczący. Niesprzyjające warunki prowadzenia działalności gospodarczej na Ukrainie (zwłaszcza dla małych firm) są główną determinantą internacjonalizacji mikro i małych firm, związaną z poszukiwaniem możliwości poza własnym krajem, czemu sprzyja też przedsiębiorczość i determinacja właścicieli przedsiębiorstw (i jej menedżerów). Badania dają konkluzję, iż na Ukrainie dominującym sposobem internacjonalizacji niewielkich firm jest ich wczesna (lub natychmiastowa) internacjonalizacja. Oznacza to, że małe firmy, nie mając możliwości rozwoju na rynku macierzystym oraz nie posiadając zdolności konkurencyjnej w stosunku do „odchudzonych” kosztowo firm niezarejestrowanych, od samego początku szukają tych możliwości na wybranych rynkach zagranicznych. 


\section{Bibliografia}

Chukhray N., Rozwój przedsiębiorczości w Ukrainie - główne problemy oraz perspektywy, [w:] A. Jackiewicz, Ł. Sułkowski (red.), Przedsiębiorczość i zarzadzanie, t. XIV, zesz. 8, cz. 1, Wydawnictwo SAN, Łódź 2013.

Epifanova I. M., Kluczowe aspekty rozwoju małych przedsiębiorstw na Ukrainie, Materiały Uniwersytetu Odeskiej Politechniki 2009, nr 1 (31).

Gierszewska G., Romanowska M., Analiza strategiczna przedsiębiorstwa, wyd. VII, PWE S.A., Warszawa 2017.

Glinkowska B., Chebotarov V. A., Малый и средний бизнес Польши и Украины: проблемь классификации и исходные институциональные основы трансформации, [w:] B. Glinkowska (red.), Internacjonalizacja przedsiębiorstw. Uwarunkowania, procesy, wyniki badań, Wydawnictwo UŁ, Łódź 2016, s. 148-158.

Glinkowska B., Kaczmarek B., Zarządzanie międzynarodowe. Strategie i studia przypadków, Wydawnictwo UŁ, Łódź 2016b.

Glinkowska B., Kaczmarek B., Zarządzanie międzynarodowe i internacjonalizacja przedsiębiorstw. Teoria i praktyka, Wydawnictwo UŁ, Łódź 2016a.

GUS, http://stat.gov.pl/statystyka-miedzynarodowa/porownania-miedzynarodowe/tablice-o-krajach-wedlug-tematow/ [dostęp 7.01.2018].

Jarosiński M., Procesy i modele internacjonalizacji polskich przedsiębiorstw, Oficyna Wydawnicza Szkoła Główna Handlowa, Warszawa 2013.

Johanson J., Vahlne J. R., The Internationalization Process of the Firm - A Model of Knowledge Development and Increasing Commitments, "Journal of International Business Studies" 1977, vol. 8, no 1.

Kodeks handlowy Ukrainy nr 436-IV z 16 stycznia 2003 r., Biuletyn Rady Najwyższej Ukrainy, 2003, nr 18, nr 19-20, nr 21-22, art. 144.

Obłój K., Strategia organizacji (wyd. II zmienione), PWE, Warszawa 2007.

Państwowa Stużba Statystyki Ukrainy, http://www.ukrstat.gov.ua/ [dostęp 7.01.2018].

Pierścionek Z., Zarządzanie strategiczne $w$ przedsiębiorstwie, Wydawnictwo Naukowe PWN, Warszawa 2011.

Pietrasieński P., Międzynarodowe strategie marketingowe, PWE, Warszawa 2005.

Przybylska K., Proces internacjonalizacji przedsiębiorstwa $w$ teorii ekonomicznej, Zeszyty Naukowe, nr 3, Wydawnictwo Wyższa Szkoła Ekonomiczna, Bochnia 2005.

Rozkwitalska M., Zarządzanie międzynarodowe, Difin sp. z o.o., Warszawa 2007.

Rymarczyk J., Internacjonalizacja i globalizacja przedsiębiorstwa, PWE, Warszawa 2004.

Wach K., Skutki akcesji do Unii Europejskiej dla polskich przedsiębiorstw, Wydawnictwo Uniwersytetu Ekonomicznego w Krakowie, Kraków 2008. 
Welch L. S., Luostarinen R. K., Internationalization: Evolution of a Concept, [w:] K. Przybylska, Born Global nowa generacja matych przedsiębiorstw, Uniwersytet Ekonomiczny w Krakowie, Kraków 2013.

The World Bank, http://www.worldbank.org/en/region/eca/publication/europe-and-central-asia-economic-update [dostęp 8.01.2018].

https://ips.ligazakon.net/document/view/T030436?bl= (akty prawne Ukrainy).

\title{
Model of internationalization of Ukrainian small enterprises
}

\begin{abstract}
The study focuses on the analysis of the ways of internationalization of micro and small Ukrainian enterprises. It contains such elements as: introduction, analysis of the functioning conditions of micro and small enterprises in Ukraine, analysis of the own research results in the following areas: understanding the nature of the internationalization process, motives and barriers to the internationalization of micro and small Ukrainian enterprises in the applied internationalization strategies. The introduction includes the purpose of the study and the characteristics of the empirical research. The internationalization of small Ukrainian enterprises has been described. The study is completed with a summary referring to all mentioned considerations. The most important conclusion from the study: micro and small Ukrainian enterprises use "early internationalization".
\end{abstract}

Keywords: internationalization, small and medium-sized enterprises, born global, enterprise, Ukraina. 